\title{
Rising Environmental Cadmium Levels in Developing Countries: Threat to Genome Stability and Health
}

John I. Anetor*

Department of Chemical Pathology, School of Clinical Medicine, College of Health Sciences, Igbinedion University, Okada, Nigeria

Department of Chemical Pathology, Toxicology/ Micronutrient Metabolism Unit, Faculty of Basic Medical Sciences, College of Medicine, University of Ibadan, Nigeria

\begin{abstract}
Cadmium (Cd) is a ubiquitous environmental pollutant of increasing worldwide concern. It is thought to be of greater concern to rapidly industrializing developing countries because of the increasing pace of industrial activities in these countries with increasing consumption and release into the environment. Traditionally, health concerns in exposed human populations have revolved around the association of $\mathrm{Cd}$ with bone disease, emphysema and possibly hypertension. Accumulating evidence suggest that $\mathrm{Cd}$ is involved in the disruption of many genomic processes, the mechanisms of which are being gradually understood. Changes in DNA methylation may be induced by cadmium leading to epigenetic alterations. Additionally, though $\mathrm{Cd}$ is not thought to induce Reactive Oxygen Species (ROS) directly because it is not capable of accepting or donating electrons under physiological conditions, 8-hydroxy deoxyguanosine (8-OHdG) (a marker of oxidative stress to DNA and a risk factor for cancer among others) has been shown to be elevated in the DNA of testes from rats treated with cadmium chloride, at least in part because Cd inhibits DNA repair mechanisms.
\end{abstract}

Cadmium is also a metabolic antagonist to Zinc (Zn), an important micronutrient involved in numerous molecular activities. This antagonism alters the physiological stoichiometric relationship between $\mathrm{Cd}$ and $\mathrm{Zn}$ leading to high $\mathrm{Cd} /$ $\mathrm{Zn}$ ratio, one consequence of which is high error rate and lack of efficient DNA repair systems leading to high mutation and genome instability culminating in many carcinogenic states, particularly prostate carcinogenesis. Cadmium has also been shown to replace $\mathrm{Zn}$ in the tumor suppressor protein, p53 thereby impairing p53's DNA binding activity and associated repair processes. The expression of the p53 protein is significantly depressed by cadmium.

Although the rising level of $\mathrm{Cd}$ in the environment is widely acknowledged, the occult threat it poses to genome stability largely through inhibition normal DNA damage repair, oxidative stress, apoptosis and health is poorly recognized. This paper examines the involvement of $\mathrm{Cd}$ in the molecular pathways of human disease, providing insight for the prevention of genome instability and associated disease susceptibility particularly cancer across populations through micronutrient intervention, aiding upregulation of the antioxidant defense and DNA repair systems.

Keywords: Cadmium; DNA repair inhibition; Environmental pollutants; Genome instability; Micronutrient intervention; Industrial activities; Oxidative stress

\section{Introduction}

Cadmium (Cd) is a non essential heavy metal belonging to group IIB of the periodic table of elements [1] which is a wide spread environmental pollutant that has recently gained greater public prominence due to its increased use in industrial processes particularly due to world-wide increase in discard of electronic -waste such as cell phones and computers containing this toxic metal [2-4]. Unlike essential trace elements such as copper, iron, selenium, zinc and others, Cd largely has no known biological function (Table 1).

Previously human exposure mainly occurred through ingestion of contaminated food or water or smoking. The increasing presence of cadmium from increasing industrial activities may now make these secondary and accentuate them and increase the potential for cadmium to be present in biological systems. The potential for cadmium to

\begin{tabular}{|l|}
\hline Electroplating and galvanizing \\
\hline Mining and processing of many metals \\
\hline Pigment in many paints and plastics \\
\hline Component of batteries \\
\hline Component in electronic circuitry in computers and cell phones. \\
\hline Welding and Ni-Cd batteries \\
\hline Printer's ink \\
\hline
\end{tabular}

Table 1: Industrial uses of cadmium. cause toxicity has been demonstrated by the results of numerous experimental and epidemiological studies. The persistent nature of $\mathrm{Cd}$ in the environment and in biological tissues has great potential health effects, especially, with respect to the role of cadmium as a human carcinogen [1,5].

A toxic peculiarity of cadmium is that exposure of cells to low, micromolar concentrations of Cd results in significant toxicity $[6,7]$ Cadmium exposure produces a variety of adverse effects in humans and animals. Normally the concentration of $\mathrm{Cd}$ is relatively low in the natural environment, but its wide distribution and long half life makes it cumulative in living cultures [8]. Chronic inhalation of Cd from a contaminated environment leads to various pathological manifestations, such as inflammation and fibrosis and eventually causes organ dysfunction and injury. Furthermore, $\mathrm{Cd}$ is considered a carcinogen and exposure to it has already been linked to cancer of

*Corresponding author: John I. Anetor, PhD, Department of Chemical Pathology, School of Clinical Medicine, College of Health Sciences, Igbinedion University, Okada, Nigeria, E-mail: anetorji@yahoo.com; jnetor@comui.edu.ng

Received January 31, 2012; Accepted April 24, 2012; Published April 26, 2012

Citation: Anetor JI (2012) Rising Environmental Cadmium Levels in Developing Countries: Threat to Genome Stability and Health. J Environ Anal Toxicol 2:140. doi:10.4172/2161-0525.1000140

Copyright: (c) 2012 Anetor. This is an open-access article distributed under the terms of the Creative Commons Attribution License, which permits unrestricted use, distribution, and reproduction in any medium, provided the original author and source are credited. 
the prostate, liver and lung. The outbreak of Itai-Itai (Ouch-Ouch) disease in the Fuchu- Toyama prefecture in Japan first brought public awareness to the health risk of exposure to $\mathrm{Cd}$ with reports of women residing in a cadmium polluted region suffering from advanced renal disease and bone disease [9]. There is also growing evidence that diseases that have genome instability as their precursors (cancer, developmental disorders etc) are on the increase [10]. There appear to be an unrecognized association between the prevalence of these diseases and the rising level of cadmium in the environment. Additionally, several recent studies have revealed the mechanisms, by which cadmium may be involved in perturbation of genome stability [11]. Bertin and Averbeck [12] have shown that cadmium has a number of cellular effects; modification of biomolecules, modulation of DNA repair and genotoxic consequences. Specifically Cd is known to impair DNA repair mechanisms and apoptosis. Cadmium is also a metabolic antagonist of zinc well recognized for its role in DNA repair mechanisms $[5,13]$. This heavy metal has also been implicated in oxidative stress, a phenomenon widely recognized for its role in DNA damage [5]. Cadmium has also been reported to impair the protein p53, a protein involved in tumor suppression through a number of mechanisms including apoptosis [14]. Very recently cadmium has been incriminated in alteration in the emerging science of epigenetics [15]. This is a recently recognized mechanism of gene expression that does not involve DNA sequence alteration. The involvement of $\mathrm{Cd}$ in these fundamental molecular processes and its implication for genome stability and health and approaches to counter or ameliorate the phenomenon has received very little attention. This contribution attempts to draw attention to this occult but real event and suggests ways to avert or at least ameliorate it by the use genome protective micronutrients (Figure 1).

\section{Industrial Uses of Cadmium and Risk of Genome Instability}

Cabrera et al. [16] have observed that this largely contributes to the contamination of vegetable crops, farmlands and irrigation water. As some of these countries export crops and vegetables grown on contaminated farmlands it means that a much larger population will be affected globally. Cadmium is selectively taken up by certain edible food items, thus food is often reported as a source of human exposure to cadmium. Even in unexposed areas of industrializing countries $\mathrm{Cd}$ is now known to be an insidious component of the food chain [17]. It is also known that workers in the occupations indicated in table 1 above are exposed to cadmium at significantly higher levels than the general public. Thus the risk of associated genome instability may be

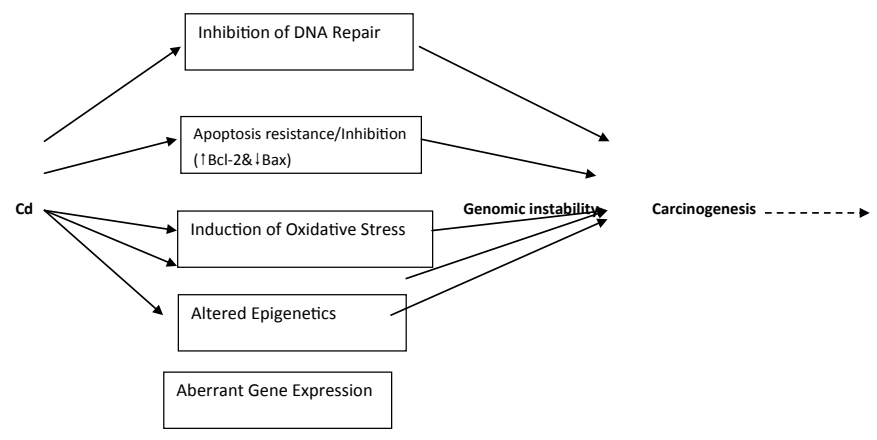

Figure 1: A schematic representation of the mechanisms involved in Cadmium-induced genomic instability. higher in these workers. Similarly, residents of areas contaminated with cadmium are exposed to higher quantities of $\mathrm{Cd}$.

\section{Cadmium in Ores and Non-recognition of Genome Instability}

Cadmium is a by-product of zinc ( $\mathrm{Zn}$ ) production and commonly occurs with zinc ores [17]. In the past cadmium pollution arose principally from mining pollution, use of non-ferrous metals and disposal of material containing or contaminated with $\mathrm{Cd}$. The worldwide production of $\mathrm{Cd}$ in 2005 was estimated to be 20,000 metric tons [5].This is in addition to cadmium generated from wastes including e-wastes. Though the scientific community had been concerned about the toxic effects of cadmium for decades its possible effects on the genome have not been explored. Cadmium is classified as a category 1 carcinogen, but is not directly genotoxic or mutagenic in bacteria. It is known to affect genome stability via inhibition of DNA repair and generation of free radical-induced damage. At the cellular level, cadmium induces oxidative stress by depletion of endogenous antioxidants such as glutathione and is associated with mitochondrial damage, induction of apoptosis and disruption of intracellular calcium signaling

\section{Cadmium in the Environment of Fast Developing Countries}

Progressive industrialization in the developing countries is currently evident and desirable to improve standard of live and income in these countries. This has culminated in the greater use of chemicals and other materials estimated to be over eighty thousand $(80,000)$ chemicals currently in use [18]. Nriagu [19] has pointed out the increasing global metal pollution and increasing production and consumption of heavy metals including, Cd since the industrial revolution. This is probably more true of the fast developing countries currently. Human exposure to $\mathrm{Cd}$ is currently a serious concern in the fast developing countries, particularly China and India [20-22]. This also applies to other developing countries that consume these pro,ducts. Satarug et al. [23] had indeed predicted that given the current rate of release of cadmium in to the environment, Cd content in the human body is likely to increase in the future. This is consonant with the prediction of Carson [24] many decades earlier about chemicals generally which has been confirmed by many subsequent investigators. The stability of the genome appears to be an ignored target of this increasing chemical burden. It is a threat to be viewed seriously and efforts at mitigating it considered a priority.

\section{Itai -Itai Disease: A Disease of Industrialization}

In the first half of the $20^{\text {th }}$ century an endemic disease was observed in a certain population in the Fuchu-Toyama prefecture of Japan; ItaiItai (Ouch-Ouch) disease that its pathogenesis involved disordered bone metabolism and kidney impairment [9]. This disease was first observed after World War II. In this disease, elevated levels of Cd in urine were found [25]. In 1968 the disease was declared by the Japanese government to be a disease related to environmental pollution. Cadmium released from a mine in the mountains was carried by the Jinzu River into the plain where the contaminated water was used to irrigate rice fields (primitive industrialization at the time). The rice plants took up Cd from the soil and consumption of contaminated rice was the main pathway of exposure of the general population. This contamination is thus originating from industrial activities which have been heightened in the rapidly industrializing developing countries 
currently. Itai- Itai disease can therefore be plausibly regarded as a disease of industrialization.

\section{Cadmium and the Human Genome}

Environmental exposures to toxic chemicals modify the genome leading to diseases including cancer. This is why cadmium is very important among others. Cadmium has thus been aptly described as a genotoxic prime environmental pollutant of great public health significance [12]. Cadmium consequently leads to higher incidence of a number of diseases. Genotoxicity is occult, of long latency but more deleterious on the long run. This is why it is considered a great omission or under estimation of the potential threat $\mathrm{Cd}$ poses to the human genome thus public health regionally and globally. Several years ago The Pacific Basin Consortium (a regional assembly of rapidly industrializing and industrialized countries), ostensibly a response to the expanding industrial activities in the Pacific Basin Rim and the associated threat to human health, oblivious of genome impact had a conference. This consortium is home to a third of the world's population including the wealthiest and the poorest countries. In this large sub- global gathering not enough prominence was given to $\mathrm{Cd}$ in its 2005 11th scientific conference inspite of emerging evidence implicating it in genome instability $[26,27]$

Cadmium is absorbed from both the gut and respiratory tract (lungs) but poorly excreted. Even though absorption takes place in the Gastrointestinal Tract (GIT) that through the respiratory tract is of greater magnitude (10\% versus $50 \%$ ) [28]. A near peculiarity of cadmium is that it is a cumulative toxicant. Once absorbed it is principally deposited in the liver and kidney both accounting for over $50 \%$ of the total body burden [17]. Though accumulated body burden may damage the kidney, hitherto considered critical target of cadmium toxicity, emerging evidence now suggest that this may be overtaken by genotoxicity $[5,12]$. This development though considered occult is real.

This is probably why Cd is now considered a human carcinogen and has been implicated in many types of cancer, prostate, lung and kidney $[1,5,29]$.

\section{Cadmium: A Human Carcinogen}

Strong evidence, based on experimental studies, exists to support the carcinogenic potential of $\mathrm{Cd}$. Cell transformation, a procedure routinely employed diagnostic in vitro test for the carcinogenic potential of chemicals, has been utilized in a number of studies to demonstrate the carcinogenic potential of cadmium and gain insight regarding the potential mechanisms underlying cadmium carcinogenesis [30-34]. The major mechanisms attributed to $\mathrm{Cd}$ carcinogenesis may broadly be classified into four major categories as follows:

\section{* Aberrant gene expression \\ * Inhibition of DNA damage repair \\ * Inhibition of apoptosis \\ * Induction of oxidative stress}

These have significant overlap among themselves. Additionally, the ability of cadmium to cause aberrant DNA methylation cannot be ignored $[35,36]$ though of minor significance compared to the above mechanisms. Other mechanisms of relative minor importance with regard to the carcinogenic potential of $\mathrm{Cd}$ are endocrine disruption [37] and cell proliferation [36].

DNA damage induced in human peripheral blood lymphocytes by industrial solid waste and municipal sludge leachates have been reported in some developing countries and it is interesting that cadmium was reported to be a major constituent in this [36-38]. This may be considered evidence in support of threat to the genome of the populations in these countries. A further insult to that already is existing from micronutrient deficiency disorders. The micronutrients particularly zinc plays vital roles in genome integrity $[38,39]$.

\section{Cadmium in the Inhibition of DNA Repair}

Maintenance of genome stability of genome stability is crucial for avoiding carcinogenesis. Many human cancers display an array of chromosomal aberrations, a characteristic referred to as genome instability. The relationship between cancer and genome instability is well recognized, nevertheless the cause of genome instability in the development of cancer, particularly the possible contribution of $\mathrm{Cd}$ is poorly understood. The DNA damage response element safeguards the integrity of the genome by uncovering abnormalities (alterations), halting cell cycle progression, and repairing DNA damage. Cadmium interferes with a number of these processes [40]

Cells with defective DNA damage responses are characterized by genomic instability.

Cadmium's ability to inhibit DNA repair has been demonstrated repeatedly $[40,41]$. Cadmium like most chemicals in general, induces cancer by genotoxic or non-genotoxic mechanisms. Exposure to cadmium results in chromosomal aberrations, sister chromatid exchange, DNA strand breaks, and DNA-protein cross links in a variety of cell lines [42-44]. DNA-strand breaks are among the most lethal forms of DNA damage; incorrectly repaired breaks can lead to gross chromosomal rearrangements, aneuploidy and ultimately carcinogenesis. DNA repair plays a very important part in maintaining genomic integrity and deficiencies in repair enzyme systems are known to promote cancer development. The potential for cadmium to cause mutation in CD59 locus, a human-hamster hybrid (AL) cell model, that is known to be highly efficient in detecting mutations involving large deletions, has been reported [45]. Palus et al. [45] have established a good correlation between Cd level and genotoxicity in peripheral blood mononuclear cells obtained subjects occupationally exposed to Cd. Despite these reports, it should however be noted that $\mathrm{Cd}$ has not been found to exert genotoxic effect in the traditionally used bacterial test systems (Ames test) instead only weak mutagenic effect was demonstrable in mammalian cell systems [46]. Other studies reported that, that very high concentrations of cadmium, about the concentration of $1 \mathrm{mM}$ were required to elicit the genotoxicity of $\mathrm{Cd}$ in some cases. Consequently, the general consensus that cadmium is at best a weak genotoxic agent, may not apply in the developing countries where protective micronutrients involved in repair processes are inadequate $[47,48]$. This implies that at such concentration Cd may still pose a significant threat in these countries.

A number of reports provide evidence that the genotoxicity of induced by cadmium is not a direct effect of the genotoxicants, but arising largely from the generation of reactive oxygen species and the attendant oxidative stress. Single strand break induced by cadmium in cultured V-79 cell was demonstrated only under aerobic conditions $[42,45]$. Studies indicate that exposure of cells to Cd resulted in the generation of 8-OHdG; a well known and reliable index of oxidative DNA damage $[45,49]$. Pre-treatment with human-hamster hybrid AL cells with buthionine sulfoxime (BOS) resulted in the depletion of cellular glutathione (GSH) and a concomitant accentuation of the genotoxicity of Cd [45], corroborating a role for ROS in cadmiuminduced genotoxicity. 
As earlier indicated, despite Cd being a weak genotoxic chemical, it exhibits remarkable potential to inhibit DNA damage repair, and this has been identified as a major mechanism underlying the carcinogenic potential of cadmium [11,41,50]. Again this may be of greater significance in the rapidly industrializing developing countries that are resource poor and suffer from malnutrition $[50,51]$.

Endogenous and exogenous factors contribute to DNA damage in cells which if not properly and timely repaired may result in genotoxic and ultimately carcinogenic consequences. The potential for cadmium to inhibit DNA damage repair has been demonstrated consistently by several investigators [52-54]. Exposure to alveolar epithelial cells to Cd significantly reduced the activity of formamidopyrimidine DNA glycosylase, an enzyme involved in the recognition and removal of oxidative DNA damage such as 8-hyroxylguanine and 8 -hydrohyadenine [40]. Alveolar epithelial cells adaptation to $\mathrm{Cd}$ has been observed to be associated with a significant loss in the ability to repair oxidative DNA damage [40]. Lewinska et al. [54] have reported that the repair of 8-oxoG in lymphocytes of cadmium exposed workers was inversely correlated with the dose and level of DNA strand breaks. Cellular GSH content has been demonstrated to be a determining factor influencing the effect of cadmium on the DNA damage repair process. Depletion of glutathione induced by cadmium in rat testes was associated with increased 8-oxoG formation as well as decreased rates 8-oxoG repair suggesting that in the absence of efficient detoxification process ROS accumulate in the cells resulting in the inhibition of DNA repair $[55,56]$.

Inability to repair DNA damage can result in the accumulation of damaged DNA which contributes to mutation and carcinogenesis. Inhibition of DNA damage repair by cadmium is also significant as regards the incidences of spontaneous cancers and those induced by other genotoxic chemicals. This is of particular import for developing countries where the Cd levels are rising and indeed may be linked with the rising incidence of cancers particularly occupational cancers in these countries [10]. In situations of Cd-induced inhibition of DNA repair, spontaneously appearing DNA damage in cells may remain unrepaired leading to genome instability and may result ultimately in mutations and spontaneous cancers.

The role of cadmium has been investigated in part as an inhibitor of DNA damage repair in smokers who have a greater risk of developing cancer particularly prostate cancer [57-59].This is because cigarette smoke contains a significant amount of cadmium and a large number of potentially genotoxic chemicals. Evidence exist that that $\mathrm{Cd}$-induced inhibition of DNA damage repair in experimental models that are exposed to cigarette smoke may facilitate the accumulation of DNA damage brought about or caused by genotoxic chemicals present in cigarette smoke, culminating in mutations that may ultimately lead to cancer. By extension, Cd co-exposure may enhance the carcinogenic potential of other genotoxic chemicals commonly found in the environment and occupational locations, or yet enable the genotoxic chemicals to cause cancer at concentrations less than those required to induce cancer following their individual exposure (potentiation).This may be very important in population with compromised micronutrient status common in many developing countries [59].

Cadmium is a metabolic antagonist of zinc; a very important micronutrient involved in DNA repair and genome stability, but unfortunately commonly deficient in populations in developing countries [59-61]. Cadmium-induced inhibition of DNA repair is believed to be due to its effects on the enzymes which play key roles in the repair process. A number of these enzymes are $\mathrm{Zn}$-dependent (members of the zinc finger family of proteins). Cadmium, because of this well known metabolic antagonism can substitute for zinc in these enzymes and proteins with substituted Cd do not perform their functions as efficiently as DNA damage repair enzymes $[39,61,62]$.

\section{Cadmium and Zinc Antagonism}

In addition to the observations above on inhibition of DNA inhibition by cadmium, zinc is a cofactor in proteins involved in oxidant defenses, DNA repair and p53 protein expression. Ho et al. [38] have examined the effect of $\mathrm{Zn}$ deficiency on oxidative stress, DNA damage and DNA repair in primary human lung fibroblast. Zinc deficiency did not only cause oxidative stress and DNA damage, but also compromised repair of the damage. Toxicity of Cd has been so dependent on disturbances of $\mathrm{Zn}$ metabolism that $\mathrm{Cd}$ has been described as an antimetabolite of $\mathrm{Zn}[62,63]$. Anetor et al. [58] in their study of cigarette smoking and the greater risk to cancer of the prostate in these subjects reported high $\mathrm{Cd} / \mathrm{Zn}$ ratio which leads to high error rates and lack of efficient DNA repair system leading to high mutation rates in prostate cancer.

\section{Cadmium, p53 Protein and Apoptosis}

The p53, tumor suppressor protein is a critical mediator of cell cycle arrest and apoptosis in response to genotoxic stress. Abrogation of p53's function is a key factor in tumor development and may result in altered DNA damage response. Cadmium replaces $\mathrm{Zn}$ in p53 and by impairing the binding of $\mathrm{p} 53$ to DNA causing genome instability. This impairment decreases the ability of cells to respond to DNA damage [63].

Apoptosis is a genetically highly regulated and conserved form of cell death which plays a key role in the development and maintenance of tissue homeostasis in multicellular organisms. Apoptosis plays an essential role in the elimination of mutated or transformed cells from the host. Consequently, for survival, cancer cells and their precursors must develop highly efficient mechanisms to avoid apoptosis. Indeed the avoidance of apoptosis is considered a hallmark of cancer cells. This may inadvertently be promoted in developing countries as a result of the rising cadmium levels given the negative effect of $\mathrm{Cd}$ on this fundamental molecular process.

\section{Cadmium and Selenium}

Selenium (Se) like $\mathrm{Zn}$ is a micronutrient modulating a variety of cellular function [64,65]. Selenium compounds are effective antioxidants and inhibitors of tumorigenesis. Elemental and organoselenium compounds at comparatively low concentrations inhibit mutagenesis, chromosome break and cell proliferation from chemical carcinogens. Rodent studies indicate a protective effect of selenium on viral or chemical -induced mammary carcinomas [66]. Uptake, transport, metabolism and physiological activity of selenium is influenced by interaction with $\mathrm{Cd}$ and other heavy metals. Selenium deficiency like that of $\mathrm{Zn}$ will be permissive of genomic instability and associated disorders. A physiological role of selenium in genome stability maintenance has been suggested [67]. Cadmium is one of the elements exhibiting high affinity for Se and exerts significant interaction at levels close to no-effect threshold levels. Schnauzer [56] has observed that exposure to low levels of Se antagonists like cadmium leads to genome instability, abolishing the cancer protecting effects selenium. Drasch et al. [57] have demonstrated that high Cd /Se ratio in human prostate is indicative of risk of prostate cancer and that the risk is greater in smokers than in non-smokers. They also observed that 
the aggressiveness and lethality of the disease is greater in smokers than in non smokers. This is not surprising in that the substantially raised Cd burden will upturn the DNA repair capability as well as inhibit or overwhelm the antioxidant capacity of selenium. Additionally, the inhibitory effect of $\mathrm{Cd}$ on apoptosis may also come to play. Cadmium also alters fidelity of DNA replication [51,52].

The rising Cd level in the emerging economies or rapidly industrializing developing countries may be an indication to increase micronutrient levels or a different RDA for Se and other genome protective micronutrients in the populations in these countries.

\section{Cadmium, Cobalt and the Genome}

Understanding of the mechanisms of toxicity of cadmium remains incomplete and appears to embrace a whole spectrum biochemical, cellular and molecular events. All mechanisms are however interrelated and advances in the study of this pervasive toxicant keep revealing more mechanisms. Cadmium has the capacity to replace cobalt, a micronutrient with close affinity to iron absorption mechanism $[67,68]$. This may not be surprising owing to the well known inverse relationship between iron and cadmium toxicity [68]. The replacement of cobalt by cadmium however has a number of biochemical and molecular importance and on genome stability. Cobalt is an important component of Cyanocobalamin, vitamin B12, which plays a vital role in purine metabolism and genome stability [65]. Thus, the replacement of Co by $\mathrm{Cd}$ is another potential mechanism of the disturbance of genome stability by cadmium exposure.

\section{Cadmium, Epigenetics and Disease}

In addition to genetic factors, the rising number of epidemiological and experimental studies provides evidence for a role for environmental toxicants in human cancer development [69]. To understand the mechanistic basis for environment associated cancers, it is crucial to understand how environmental factors interact with genes that are involved in human malignancies. Recent reports strongly suggest that epigenetic changes of DNA methylation and histone modifications (methylation and acetylation) play crucial role in the development of human cancers [70].

Epigenetics encompasses heritable alteration in gene expression and chromatin without accompanying changes in DNA sequence (independent of DNA sequence changes). Epigenetic changes arise from interplay of DNA Methylation, post-translational histone protein modification, RNA mediated gene silencing and other currently unknown mechanisms. Epigenetics is essential for normal development and differentiation.

Deregulation of epigenetic information has been associated with a variety of human diseases, notably cancer. The recent revelation [71] that environmental factors can deregulate epigenetic information and alter gene expression pattern in a heritable manner leading to malignant transformation is instructive. Cadmium not surprisingly has been linked with this epigenetic perturbation [15,72]. Waalkes et al. [11] have reported that exposure to cadmium is linked with several tumor types including cancer of the lungs, liver, prostate, kidney and stomach. Accumulating evidence indicates that aberrant DNA methylation and histone modification patterns may be induced by excessive exposure to cadmium in the environment. Cadmium is an enzyme inhibitor showed to efficiently inhibit DNA methtyltransferase; leading to hypomethylation $[15,71,72]$. Prolonged exposure to Cd can also lead to hypermethylation, suggesting, that $\mathrm{Cd}$ may have triggered global hypomethylation and promoter specific hypermethylation both of which are implicated in carcinogenesis. Available current evidence suggests that there is currently excessive exposure to $\mathrm{Cd}$ in the environment $[4,23]$. Cadmium is currently accepted as an unequivocal carcinogen $[1,5]$. It is also in light of emerging evidence considered an epimutagen that can deregulate epigenetic information, alter gene expression patterns in a heritable manner leading to malignant transformation which is always preceded by genome instability $[15,71]$. Thus from both the genetic and epigenetic perspectives Cd leads to genome instability that is a factor in carcinogenesis.

\section{Cadmium and Prostate Carcinogenesis: A Probable Clinical Evidence of Genome Instability}

Genome stability is essential for normal tissue replication and health of many organs including the prostate. Genome instability is one of the defining features of cancer cells, and is associated with both tumorigenesis and tumor progression. The prostate is one organ that accumulates $\mathrm{Cd}$ and it is probable that this may be associated with genome instability a precursor of tumorigenesis.

Prostate cancer is currently considered the most common cancer in men accounting for $29 \%$ of fresh cases of cancer [73]. The environmental contribution from the rising level of $\mathrm{Cd}$ is poorly recognized. Cursory appraisals suggest possible positive correlation. Experimental and epidemiological evidence exist for a potential association between $\mathrm{Cd}$ exposure and the prostate in humans and rodents [74-77]. Cadmium accumulates in men as they age owing to slow excretion rate $[78,79]$. The prostate is considered one of the organs of the body with high bioaccumulation of cadmium $[31,80]$. Patients with prostate cancer appear to have higher circulating and organ level of $\mathrm{Cd}$ probably by displacing $\mathrm{Zn}[56,58,81]$.

\section{Cadmium and Prostate Epithelial Cells Transformation}

Cadmium exposure has particularly been reported to cause neoplastic transformation of human epithelial cells dose dependently $[30,31,82]$. The potential involvement of apoptosis as mechanism for cadmium carcinogenesis has been demonstrated by a series of studies conducted by Waalkes group $[26,82,83]$. These investigators exposed normal human prostate epithelial cells to $10 \mu \mathrm{M} \mathrm{CdCl}_{2}$ resulted in their malignant transformation [30]. These Cd- transformed cells exhibited loss of contact inhibition and changed into highly invasive and occasionally malignant adenocarcinomas when injected subcutaneously in immune compromised mice. In a second study by the same investigators it was observed that exposure of RWPE-1 cells to $\mathrm{CdCl}_{2}$ resulted in activation of genes, such as c-jun and c-myc, genes that are involved in cell proliferation [82]. In this study the expression of p53 tumor suppressor gene was significantly reduced in the Cdtreated cells compared to the control at intervals beyond 48-hour post exposure to cadmium chloride. A disproportionate number $(>65 \%)$ of the Cd exposed cells died following exposure to cadmium and this was attributed to induction of apoptosis. About $35 \%$ of the experimental cells survived and these were found to be normal and resistant to Cd-induced apoptosis. Additionally, the Cd-resistant population of cells demonstrated 2.5-fold more metallothionein content compared to normal, untreated RWPE-1 cells. Thus it appears that its ability to induce apoptosis and cell death notwithstanding, Cd may enhance the selective enrichment of genetically damaged and apoptosis resistant cells with enhanced proliferative capacity culminating in malignant transformation.

Goyer et al. [75] have also reported that longer exposure to the same dose of cadmium caused emergence of malignant phenotype 
resistant to apoptosis, increasing cell proliferation rate, disruption in DNA repair mechanisms, broad based changes in gene expression and epigenetic expression patterns. Cadmium exposure has also been observed to accelerate transit through the cell cycle of prostate epithelial cells, aborting sub-G1 peak and inhibition of apoptosis [72]. Taken together, these data suggest major changes in transcriptome expression and probably partly the molecular mechanism of $\mathrm{Cd}$ induced neoplastic transformation of prostate epithelial cells. This appears to highlight genomic alterations associated with Cd exposure that may become more prominent and prevalent with the rising environmental Cd levels.

\section{Cadmium and Mammary Carcinogenesis}

Breast cancer in females like prostate cancer in males may also be another consequence of increasing levels of $\mathrm{Cd}$ in the environment. In females mammary carcinogenesis has been linked with increased exposure to $\mathrm{Cd}$ [84]. Interactive effects of selenium and $\mathrm{Cd}$ on mammary tumor development and growth in MMTV-infected models has been reported. Mammary gland and the prostate are known to share some tissue ancestry. Thus both breast and prostate cancers may be diseases to watch with the rising environmental cadmium levels.

\section{Cadmium and Transgenerational Events}

An unsettling aspect of the rising cadmium levels in the environment is the possible transgenerational effects [85]. Genetic stability and integrity are important in maintaining accurate DNA replication. DNA disruption leads to gene rearrangements, translocations, amplifications and deletions which can contribute to cancer development preceded by genome instability. Transgenerational occurrences are not unlikely given the molecular and biochemical mechanisms of $\mathrm{Cd}$ toxicity $[86,87]$.

\section{Cadmium and background Cancer}

Exposure to $\mathrm{Cd}$ is on the increase and given its involvement in genomic aberrations, raises the probability for cancer manifestation now and in the future. It is most probable that offspring of exposed parents may become of cancer prone age soon and this may be erroneously interpreted as genetic in nature. Follow up studies of workers and populations in polluted areas will be important. For the fast developing industrializing countries combination of increased $\mathrm{Cd}$ exposure and co-existent nutritional deficiencies which are also prevalent in these countries may increase the incidence of genome instability and attendant carcinogenesis. Studies have demonstrated that cadmium is a complex carcinogen and that the mechanisms involved in cadmium carcinogenesis are multifactorial. The rising and persistent nature of cadmium in the environment and consequently in biological tissues may have serious consequences for the genome and thus for carcinogenic potential. The increasing persistence of high levels of $\mathrm{Cd}$ in the environment has considerable health implications. This implies that populations in the fast developing countries are at great risk of the toxic potentials of $\mathrm{Cd}$, particularly genome instability which had not been hitherto given sufficient attention. As previously indicated, Cd exposure can result in the inhibition of normal DNA damage repair through the mechanisms outlined in cells. Experimental evidence also exists that indicate that $\mathrm{Cd}$ inhibits apoptosis and may contribute to the development of a population of apoptosis-resistant cells. These attributes of Cd i.e. persistence in the biological tissues secondary to its persistence in the environment, inhibition of DNA damage repair processes and apoptosis at least put the genome of the populations in fast industrializing countries at great risk. Synergistic interaction between $\mathrm{Cd}$ and other toxicants in the environment may further accentuate the potential of genome instability in populations in these countries. The high burden of cadmium content in the cells may prevent the repair of DNA damage secondary to other genotoxic chemicals to which such populations are also simultaneously exposed. In the same vein, Cd-induced inhibition of apoptosis may block the elimination of genetically damaged cells resulting in accumulation in the body and leading to attendant altered genome integrity. As previously seen, Cd may stimulate the proliferation of such genetically injured and apoptosis-resistant cells in those individuals. Thus through these processes $\mathrm{Cd}$ may potentiate other carcinogenic substances to contribute to genome instability (multiplier effect) and ultimately lead to the carcinogenic process at no effect level concentrations of those substances.

Further research appears desirable to explore the potential of Cd's contribution to genome inability in countries experiencing greater utilization of cadmium in manufacturing processes and end consumers who contribute to environmental $\mathrm{Cd}$ level through inappropriate disposal. Maintenance of genome stability is of fundamental importance for counteracting carcinogenesis. Many human genome instability syndromes exhibit predisposition to cancer. Both nutritional deficiency and toxicity can compromise the integrity of the genome; ineffective DNA damage responses and repair.

\section{Cadmium Exposure and Chemoprevention}

The removal of cadmium from the environment is not pragmatic. Agreeably, its level can be mitigated. A more acceptable approach to protect the population against occult genome instability may be chemoprevention. The potential effect of inorganic micronutrients on alleviating genome instability syndromes warrants all the attention. It is intuitive to explore the possibility that micronutrients may be promising agents for treating genomic instability syndromes through modulation of redox status and genomic stability [88,89]. This may be a practical approach of preventing cancer, preferably at the preneoplastic stage, using relatively non-toxic dietary chemical entities to halt, reverse or delay the carcinogenic process. A key mechanism of action of chemopreventive agents being restoring genome stability by counteracting oxidative stress and promoting the apoptotic pathway makes them possible antidotes to the rising threat of $\mathrm{Cd}$ in the environment. Chemoprevention has been described as a pragmatic approach to contain the consequences of rising environmental $\mathrm{Cd}$ levels and concomitant genomic instability which accelerates malignant transformation $[60,90,91]$. This appears a high priority area for the fast industrializing countries. Bull and Fenech [92] in agreement with this view have observed that it is becoming increasingly evident that the risk for developmental and degenerative disease increases with more DNA damage, which in turn is dependent on nutritional status; largely the optimal concentration of micronutrients for preventing genome damage. These investigators further observed that that genome damage is also dependent on genetic polymorphism that alter the function of genes involved directly or indirectly in replication and that the development of dietary patterns, functional foods and supplements that are designed to improve genome health maintenance individuals with specific genetic background would be beneficial.

\section{Nutrigenomics: Another Antidote}

Though this may remotely be considered aspect of chemoprevention it is specifically aimed at genome protection. Nutrigenomics is the integration of genomic science with nutrition to modulate genetic characteristics. It has been recently broadened to encompass nutritional 
factors that protect genome damage. This field and its potential has been consistently reviewed by Fenech and his colleagues $[69,93,94]$. It appears a promising field that can be adequately exploited to reverse or prevent occult genome instability.

\section{Miscellaneous Aberrant Genomic Observations}

Liu et al. [94] have shown in plants that Cd pollution in the range 30-120 $\mathrm{mg} / \mathrm{l}$ using random amplified polymorphic DNA (RAPD) profiling that $\mathrm{Cd}$ has genotoxic effects. They found that the effects were dose dependent. These observations suggest that even plants are not spared the genomic instability that has been observed in animals and animal components. This implies far reaching significance of the consequences of the rising environmental cadmium levels in the developing countries.

Exploring the mechanism of cadmium-induced genomic instability that may lead to carcinogenesis, Singh et al. [95] reported aberrant expression of cell cycle and DNA repair genes resulting in increased cell proliferation. The results specifically revealed that short-term exposure to lower doses of Cd significantly increased the growth of TM3 cells, a mouse testicular leydig cell line. In contrast, higher doses were very toxic and lethal to cells. Long- term exposure to higher doses of Cd caused increased cell survival and acquisition of apoptotic resistance. Gene expression analysis demonstrated expression of the anti-apoptotic gene $\mathrm{Bcl}-2$ and reduced expression of the pro-apoptotic gene Bax. Additionally, decreased expression of genes for maintenance of DNA methylation, DNMT1, and DNA repair, OGG1 and MYH was also exhibited by the cells after $24 \mathrm{~h}$ exposure. Like the study of Liu et al. [94], RAPD assay revealed genomic instability in cells with chronic exposure to cadmium, the form of exposure common in the general population. This study shows that among the mechanisms of $\mathrm{Cd}$ induced- genome instability include, increased cell survival through increased expression of anti-apoptotic Bcl-2, and decreased expression of pro-apoptotic Bax.

\section{Conclusion}

It is indisputable that the spate of industrialization in developing countries is contributing substantially to the rising levels of cadmium in the environment. Current understanding suggests that through inhibition of DNA repair mechanisms, inhibitory effects on apoptosis/ resistance, induction of oxidative stress, epigenetic mechanisms and aberrant gene expression this can lead to genome instability in the population. This is a precursor to carcinogenesis and may indeed be at least in part the underlying explanation for the increasing incidence of cancer in these countries. Genome instability though occult should now be considered the critical endpoint of the rising cadmium levels in these countries. This may lead to accelerated malignant transformation of cells. Chemoprevention appears a pragmatic approach to check this inevitable exposure to rising environmental Cd levels. Chemoprevention including nutrigenomics is accepted to be a realistic and fundamental measure to contain the consequences of this rising environmental Cd level. Developing countries must regard this as a priority area to forestall the occult deleterious effect of Cd on the genome and the health of the population.

\section{Acknowledgement}

I wish to acknowledge Miss Adeleye Osimhiarherhuo and Mr Damilola Samson Akinduko, Postgraduate students in the Department of Chemical Pathology, University of Ibadan for their technical assistance (graphics).

\section{References}

1. IARC (International Agency for Research on Cancer) (1993) Cadmium and Cadmium Compounds. IARC monograph Eval carcinog Risk Hum 58: 119-238.
2. Järup $L$ (2008) Hazards of heavy metal contaminations. Br Med Bull 68: 167 182.

3. Rydh CJ, Svărd B (2003) Impact on global metal flows arising from the use of portable rechargeable batteries. Sci Total Environ 302: 167-184.

4. Wong CSC, Duzgorin-Aydin NS, Aydin A, Wong MH (2007) Evidence of excessive releases of metals from primitive e-waste processing in Guiyu, China. Environ Pollut 148: 62-72.

5. Joseph P (2009) Mechanism of cadmium carcinogenesis. Toxicol Appl Pharmacol 238: 272-279.

6. Othumpangat S, Kashon M, Joseph P (2005) Eukaryotic translation initiation factor $4 \mathrm{E}$ is a cellular target for toxicity and death due to exposure to cadmium chloride. J Biol Chem 280: 25162-25165.

7. Badisa VL, Latinwo LM, Odewumi CO, Ikediobi CO, Badisa RB, et al. (2008) Cytotoxicity and stress gene Microarray analysis in cadmium-exposed CRL1439 normal rat liver cells. Int J Mol Med 22: 213-219.

8. Sugita M, Tsuchiya, K (1995) Estimation of variation among individuals of biological half-time of cadmium calculated from accumulated data. Environ Res 68: 31-37.

9. Tsuchiya K (1978) Etiology of itai itai disease In: Cadmium Studies in Japan: A review. Elsevier North Holland Biomedical Press pp 269-300.

10. Tomatis L, Huff $\mathrm{J}$ (2001) Evolution of cancer and primary prevention. Environ Health Perspect 109: A458-A460.

11. Waalkes MP (2000) Cadmium carcinogenesis in review. J Inorganic Biochem 79: 241-244.

12. Bertin G, Averbeck D (2006) Cadmium: cellular effects, modifications of biomolecules, modulation of DNA repair and genotoxic consequences (a review). Biochimie 88: 1549-1559.

13. Norberg GF (2009) Historical perspective of cadmium toxicology. Toxicol APP Toxicol 238: 192-200.

14. Ho E (2004) Zinc deficiency, DNA damage, and cancer risk. J Nutr Biochem 15: $572-578$

15. Takiguchi M, Achanzer WE, Qu W, Li G, Waalkes MP (2003) Effects of cadmium on DNA-(cytosine) methtyltransferase activity and DNA methylation status during cadmium- induced cellular transformation. Exp Cell Res 286: 355365.

16. Cabrera C, Ortega E, Lorenzo ML, López MC (1998) Cadmium contamination of vegetable crops, farmlands and irrigation waters. Rev Environ Contam Toxicol 154: 55-81.

17. World Health Organization (WHO) (1992). Cadmium. Environmental Health Criteria No 134.

18. Pimental D, Tort M, D'Anna Krawic, Gerger J, Shribery M, et al. (1995) Ecology of increasing disease: population growth and environmental degradation. Biosci 48: 817-826.

19. Nriagu JO (1996) History of global metal pollution. Science. 272: 223-224.

20. Sun LN, Zhang YH, Sun TH, Gong ZQ, Lin X, et al. (2006) Temporal-Spartia distribution and variability of cadmium contamination in soils in Shenyang Zhangshi Irrigation area, China. J Environ Sci (China) 18: 1241-1246.

21. Govil PK, Sorille JE, Murthy MN, Sujutha D, Reddy GL, et al. (2007) Soil contamination of heavy metals in the Katedon Idustrial Development Area, Hyderabad, India. Environ Monit Assess 140: 313-323.

22. Yan S, Ling QC, Baoz Y (2007) Metals contamination in soils and vegetables in metal smelter contaminated sites in Huangshi, China. Bull Environ Contam Toxicol 79: 361- 366

23. Satarug S, Baker JR, Urbenjapol S, Haswell-Elkins M, Reilly PE, et al. (2003) A global perspective on cadmium pollution and toxicity in non-occupationally exposed population. Toxicol Lett 137: 65-83.

24. Carson RL (2002) Silent Spring. Mariner Books New York.

25. Ishizaki A (1969) On the so called itai itai disease. Nihon Ishikai Zasshi 62 242-249

26. Achanzer We, Webber MM, Waalkes MP (2002) Altered apoptotic gene expression and acquired apoptotic resistance in cadmium-transformed human prostate epithelial cells. Prostate 52: 236-244. 
Citation: Anetor JI (2012) Rising Environmental Cadmium Levels in Developing Countries: Threat to Genome Stability and Health. J Environ Anal Toxicol 2:140. doi:10.4172/2161-0525.1000140

Page 8 of 9

27. Arnold RG, Carpenter DO, Kirk D, Koh D, Armour MA, et al. (2007) Meeting report: Threat to human health and environmental sustainability in the pacific basin. Environ Health Perspect 115: 1170-1174.

28. NTP (2004) Cadmium and cadmium Compounds. In: 11th Report on Carcinogenesis. Research Triangle Park.

29. Abshire MK, Devor DE, Diwan BA, Shaughnessy Jr JD, Waalkes MP (1996) In vitro exposure to cadmiu in rat L6 myoblasts can result in both enhancement suppression of malignant progression in vivo. Carcinogenesis 17: 1349-1356.

30. Achanzar WE, Diwan BA, Liu J, Quader ST, Webber MM, et al. (2001) Cadmium -induced malignant transformation of human prostate epithelial cells. Cancer Res 61: 455-458.

31. Joseph P, Lei Y-X, Ong TM (2004) Up-regulation of expression of expression of translational factors- a novel molecular mechanism for cadmium carcinogenesis. Mol Cell Biochem 255: 93-101.

32. Joseph P, Lei Y-X, Whong WZ, Ong TM (2002b) Oncogenic potential of mouse translation elongation factor- 1 delta, a novel cadmium responsive protooncogene. J Biol Chem 277: 6131-6136.

33. Joseph P, O'Kernick CM, Othumpangat S, Lei Y-X, Yuan BZ, et al. (2004) Expression profile of eukaryotic translation factors in human cancer tissues and cell lines. Mol Carcinog 40:171-179.

34. Huang D, Zhang Y, Qi Y, Chen C, Ji W ( 2008) Global DNA hypomethylation, rather than reactive oxygen species (ROS), a potential facilitator of cadmiumstimulated k562 cell proliferation. Toxicol Lett 170: 43-47.

35. Benbrahim-Tallaa L, Liu J, Webber MM, Waalkes MP (2007a) Estrogen signaling and disruption of androgen metabolism in acquired androgenindependence during cadmium carcinogenesis in human prostate epithelia cells. Prostate 67: 135-145

36. Benbrahim-Tallaa L, Waterland RA, Dill AL, Webber MM, Waalkes MP (2007b) Tumor suppressor gene inactivation during cadmium-induced malignant transformation of human prostate cells correlates with overexpression of de novo DNA methyltransferase. Environ Health Perspect 115: 1454-1459.

37. Bakare AA, Pandey AK, Bajpayee M, Bharga VD, Chowdhuri DK, et al. (2007) DNA damage induced in human peripheral blood lymphocytes by industrial solid waste and municipall sludge leachates. Environ Mol Mut 48: 30-37.

38. Ho E, Courtemanche C, Ames BN (2003) Zinc deficiency induces oxidative DNA damage and increases p53expression in human lung fibroblasts. J Nutr 133: $2543-2548$

39. Potts RJ, Bespalov IA, Wallace SS, Melamede RJ, Hart BA (2001) Inhibition of oxidative DNA repair in cadmium-adapted alveolar epithelial cells and the potential involvement of metallothionein. Toxicology 161: 25-38

40. Giaginis C, Gatzidou E, Theocaris S (2006) DNA repair system as targets of cadmium toxicity. Toxicol Appl Pharmacol 213: 282-290.

41. Ochi T, Ohsawa M (1985) Participation of active oxygen species in the induction of chrosomal aberrations by cadmium chloride in cul;tured Chines hamster cells. Mutat Res 143: 137-142.

42. Misra RR, Smith GT, Waalkes MP (1998) Evaluation of the direct genotoxic potential of cadmium in four different rodent cell lines. Toxicology 126: 103-114.

43. Fatur T, Tusek M, Falnoga I, Scancar J, Lah TT, et al. (2002) DNA damage and metallothionein sythesis in human hepatoma cells (HepG2) exposed to cadmium. Food Chem Toxicol 40: 1069-1076.

44. Filipic M, Hei TK (2004) Mutagenicity of cadmium in mammalian cells: implication of oxidative DNA damage. Mutat Res 546: 81-91.

45. Palus J, Rydzynski K, Dziubaltowska E, Wyszynska K, Natarajan A-T, et al. (2003) Genotoxic effect of occupational exposure to lead and cadmium. Mutat Res 540: 19-28.

46. Rossman TG, Roy NK, Lin WC (1992) Is cadmium genotoxic IARC Sci Publ 367-375.

47. Underwood BA, Smitasiri S (1999) Micronutrient malnutrition: policies and programmes for control and their implications. Ann Rev Nutr 19: 303-335.

48. Mikhailova MV, Littlefield NA, Hass BS, Poirier LA, Chou MW (1997) Cadmiuminduced 8-hydroxydeoxyguanosine formation, DNA strand breaks and antioxidant enzyme activities in lymphoblastoid cells. Cancer Lett 115: 141 148.
49. Waalkes MP (2003) Cadmium carcinogenesis. Mutat Res 533: 107-120.

50. Nweke OC, Sanders WH III (2009) Modern Environmental health hazards: a public health issue of increasing significance in Africa. Environ Health Perpect 117: $863-870$.

51. Williams PL, James RC and Roberts SM (2000) Chemical carcinogenesis. In: Principles of Toxicology: Environ Ind Appl John Wiley and Sons Inc, NY 278

52. Joseph P, lei YX, Ong TM (2004a) Upregulation of expression of translation factors -a novel molecular mechanism for cadmium carcinogenesis. Mol Cell biochem 255: 93-101.

53. Joseph P, O'Kernick CM, Othumpangat S, Lei YX, Yuan BZ, et al. (2004) Expression profile of eukaryotic translation factors in human cancer tissues and cell lines. Mol Carcinog 40: 171-179.

54. Lewinska D, Arkusz J, Stanczyk M, Palus J, Dziubaltowska E, et al. (2007) Comparison of the effects of arsenic and cadmium on benzo (a) pyreneinduced micronuclei in mouse bone-marrow. Mutat Res 632: 37-43.

55. Hirano T, Yamaguchi $Y$ and Kasai $H$ (1997) Inhibition of 8-hydroxguanine repair in testes after administration of cadmium chloride to GSH-depleted rats. Toxicol Appl Pharmacol 147: 9-14.

56. Schrauzer GN (1987) Effects of selenium antagonists on cancer susceptibility: new aspects of chronic metal toxicity. J UOEH 9: 208-215.

57. Drasch G, Schopfer J, Schrauzer GN (2005) Selenium/ cadmium ratios in human prostate cancer risk of smokers and non-smokers and relevance to cancer protective effect of selenium. Biol Trace Elem Res 103: 103-107.

58. Anetor JI, Ajose F, Anetor GO, lyanda AA, Babalola OO, et al. (2008) High cadmium/ zinc ratio in cigarette smokers : potential implications as a biomarke of risk of prostate cancer. Nig J Physiol Sci 23: 41-49.

59. WHO (World Health Organization) (2002) The World Health Report 2002: Reducing Risks, Promoting healthy Life. World Health Organization, Geneva.

60. Anetor JI, Anetor GO, Udah DC, Adeniyi FAA (2008) Chemical carcinogenesis and chemoprevention: scientific priority area in rapidly industrializing developing countries. Afr J Environ Sci Tech 2: 150-156.

61. O'Connor TR, Graves RJ, de Murcia G, Castaing B, Laval J (1993) FpG protein of Escherichia coli is a zinc finger protein whose cysteine residues have have structural and/ or functional role. J Biol Chem 268: 9063-9070.

62. Vigliani EC (1969) Yant Memorial Lecture. The biopathology of cadmium. Am Ind Hyg Ass J 30: 329-340.

63. Meplan C, Mann K, Hainaut P (1999) Cadmium induces conformational modifications of wide-type p53 and suppresses p53 response to DNA damage in cultured cells. J Biol Chem 274: 31663- 31670.

64. Arthur JR, Nicol F, Beckett GJ (1993) Selenium deficiency, thyroid hormone metabolism and thyroid hormone deiodinases. Am J Clin Nutr 57: 236s-239s.

65. Tolonen M (1990) Vitamins and Minerals in Health and Nutrition. Ellis Horwood Limited, Chichester, West Sussex, England 149-197.

66. Cheng W-H (2009) Impact of inorganic nutrients on maintenance of genome stability. Environ Mol Mutagen 50: 349-360.

67. Hamilton DL, Valberg LS (1974) Relationship between cadmium and iron absorption. Am J Physiol 227: 1033-1037.

68. Flanagan PR (1993) The intestinal interaction between cadmium and iron. In: Elsehans B, Forth W, and Schumann K (Eds). Metal- Metal Interactions, Bertelsmann Foundation Publishers, Gutersloh, Germany 42-55.

69. Fenech M (2002) Micronutrients and genomic stability: a new paradidgm for recommended dietary allowances (RDAs). Food Chem Toxicol 40: 1113-1117.

70. Feinberg AP, Tycko B (2004) The history of cancer epigenetics. Nat Rev Cancer 4: 143-153.

71. Herceg Z (2007) Epigenetics and cancer: towards an evaluation of the impact of environmental and dietary factors. Mutagenesis 22: 91-103.

72. Bakshi M, Zhang X, Godoy-Tondidor, Cheng- Rys, Sartor MA, et al. (2008) Transcriptome analysis in normal prostate epithelial cells exposed to low-dose cadmium: oncogenic and immunomodulations involving the action of tumo necrosis factor. Environ Health Perpect 116: 769-776.

73. Jemal A, Siegel R, Ward E, Murray T, Xu J, et al. (2007) Cancer Statistics 2007 CA Cancer J Cin 57: 43-66. 
Citation: Anetor Jl (2012) Rising Environmental Cadmium Levels in Developing Countries: Threat to Genome Stability and Health. J Environ Anal Toxicol 2:140. doi:10.4172/2161-0525.1000140

Page 9 of 9

74. Waalkes MP, RehmS, Riggs CW, Bare RM, Devor DE, et al. (1989) Cadmium carcinogenesis in male wistar [ $\mathrm{Cr} \mid:(\mathrm{W} 1) \mathrm{BR}]$ rats : dose- response analysis of effects of zinc on tumor induction in the prostate, in the testes, and at the injection site. Cancer Res 49: 4282-4288.

75. Goyer RA, Liu J, Waalkes MP (2004) Cadmium and Cancer of the prostate and testes. Biometals 17: 555-558.

76. Vinceti M, Venturelli M, Sighinolfi C, Trerotoli P, Bonvian F, et al. (2007) Case control study of toenail cadmium and proststate cancer risk in Italy. Sci Total Environ 373: 77-81.

77. Baecklund M, Pedersen NL, Bjorkman L, Vanfer M (1999) Variation in blood concentrations of cadmium and lead in the elderly. Environ Res 80: 222- 230.

78. Satarug S, Moore MR (2004) Adverse health effects of chronic exposure to low-level cadmium in food stuffs and cigarette smoke. Environ Health Perspect 112: $1099-1103$

79. Lindegaard PM, Hansen SD, Christensen JE, Andersen BB, Andersen O (1990) The distribution of cadmium within the human prostate. Biol Trace Elem Res 25: 97-104.

80. Brys M, Nawrocka AD, Miekos E, Zydek C, Foksinski M, et al. (1997) Zinc and cadmium analysis in human prostate neoplasms. Biol Trace Elem Res 59: $145-152$

81. Nakamura K, Yasusunagay, Ko D, Xu LL, Moui JW, et al. (2002) Cadmiuminduced neoplastic transformationof human prostate epithelial cells. Int $\mathrm{J}$ Oncol 20: $543-547$.

82. Achanzar WE, Achanzar KB, Lewis JG, Webber MM, Waalkes MP (2000) Cadmium induces c-myc, p53 and c-jun expression in normal human p;rostate epithelial cells as a prelude to apoptosis. Toxicol Appl Pharmacol 164: 291-300.

83. Yuan C, Kadiiska M, Achanzer WE, Mason RP, Waalkes MP (2000) Possible role of caspase-3 inhibition in cadmium-induced blockage of apoptosis. Toxicol Appl Pharmacol 164: 321-329.

84. Scrauzer GN et al. (2008) Interactive effects of selenium and cadmium on mammary tumor development and growth in MMTV- infected mice: a model study on the roles of cadmium and selenium in human breast cancer. Biol Trace Elem Res 123: 27-34

85. Nomura $T$ (2008) Transgenerational effects from exposure to environmenta toxic substances. Mutat Res 659:185-193.

86. Anderson D, Brinkworth MH (2007) Male-Mediated Developmental Toxicity, RSC Publishing, Cambridge, UK, pp 134-148.

87. Yu X, Hong S, Faustman EM (2008) Cadmium-induced activation of stress signaling pathways, disruption of ubiquitin -dependent protein degradation and apoptosis in primary sertoli cell-gonocyte cocultures. Toxicol Sci 104: 385-396.

88. Surh YJ (2003) Cancer chemoprevention with dietary phytochemicals. Nat Rev Cancer 3: 768-780

89. Cohen SM, Arnold LL (2011) Chemical carcinogenesis. Toxicol Sci 120: S76 S92.

90. Kundu JK, Surh YJ (2008) Inflammation: Gearing the journey to cancer. Mutat Res 659: 15-30.

91. Fenech M (2004) Genome health Nutrigenomics: nutrition and the science of optimum genome maintenance. Asia Pac J Clin Nutr 13: S15.

92. Bull C, Fenech M (2008) Genome-health nutrigenomics and nutrigenetics: nutritional requirements or 'nutriomes' for chromosomal stability and telomere maintenance at the individual level.. Proc Nutr Soc 67: 146156.

93. NTP (National Toxicology Programme) (2004) Cadmium and cadmium compounds. In: $11^{\text {th }}$ Report on Carcinogens. Research Triangle Park, NC: National Toxicology Programme, III-42-III-44.

94. Liu W, Li PJ, Qi XM, ZhouQX, Zhang L, et al. (2005) DNA changes in barley (Hordeum vulgare) seedlings induced by cadmium pollution using RPD analysis. Chemosphere 61: 158-167.

95. Singh K, Kumari R, Pevey C, Jackson D, Dumond JW (2009) Long duration exposure to cadmium leads to increased cell survival, decreased DNA repair capacity and genomic instability in mouse testicular leydig cells. Cancer Let 279: 84-92. 